\title{
Population growth and re-urbanization in Spanish inner cities: The role of internal migration and residential mobility
}

\author{
ANTONIO LOPEZ-GAY
}

\begin{abstract}
Résumé
Après 25 années de décroissance démographique intense, les centres-villes de Barcelone et de Madrid ont connu une remarquable croissance démographique au cours de la dernière décennie. Des tendances similaires mais moins intenses ont été observées dans les plus grandes villes espagnoles. La croissance démographique a repris au centre de Valence, elle est soutenue dans celui de Séville, et la décroissance du centre-ville de Bilbao observée dans les deux dernières décennies a cessé. Ainsi, les plus grandes métropoles d'Espagne illustrent le processus de ré-urbanisation que les autres villes d'Europe septentrionale telles que Rome, Milan, Turin et Marseille connaissent actuellement et que les autre grandes villes de l'Europe du Centre et du Nord, ainsi que des États-Unis, ont connu durant les deux dernières décennies du 20ème siècle. Dans le cas de l'Espagne, l'arrivée et l'installation d'une population étrangère dans les centres-villes ont joué un rôle majeur dans ce retour de croissance. Cependant, le gain net en population ne doit pas cacher un solde migratoire négatif que les centres-villes persistent à montrer avec les périphéries de ces métropoles. Il a été néanmoins observé que les centres sont devenus plus attractif pour les résidents des métropoles. Dans certains cas, une augmentation remarquable des taux d'émigration des municipalités de la métropole vers le centre-ville a été observée. De même, la proportion de résidents qui quittent le centre pour d'autres parties de la métropole décroit chaque année. L'objectif de cet article est d'analyser ces mouvements de retour vers le centre-ville des plus grandes métropoles d'Espagne d'un point de vue essentiellement géo-démographique. L'exhaustivité historique et géographique du Registre des mouvements résidentiels d'Espagne - une base de données qui inclu $100 \%$ des mouvements résidentiels ainsi que les caractéristiques des migrants pour tout le pays - permet l'identification des flux de mobilité résidentielle entre le centre et la périphérie, de
\end{abstract}

1. Centre d'Estudis Demogràfics, Universitat Autònoma de Barcelona, Spain. 
leur évolution temporelle, et de la structure démographique des migrants concernés.

\section{Mots-clés}

Démographie urbaine, ré-urbanisation, mobilité résidentielle, centre-ville, Europe du Sud.

\section{Summary}

After 25 years of intense population decrease, the inner cities of Barcelona and Madrid have experienced a remarkable increase in population during the last decade. Less intense trends in the same direction have also been observed in the largest Spanish cities. Population growth has restarted in Valencia's inner city, Seville's urban core continues to grow, and the population decrease experienced in the central city of Bilbao for the last two decades has ceased. Thus, Spain's largest metropolitan areas reflect the re-urbanization processes that other southern European cities, such as Rome, Milan, Turin and Marseille, are currently undergoing and that many other cities in central and northern Europe and the United States underwent during the last two decades of the 20th century. In the Spanish case, the arrival and settlement of a foreign population in the urban centers has played a major role in this comeback. However, the total gains in population in these areas should not hide the negative migratory balance that central cities continue to exhibit in the residential relations within their metropolitan areas. Nevertheless, it has been observed that central areas have become more attractive to metropolitan residents. In certain cases, a remarkable increase in the out-migration rates from metropolitan municipalities to the central city has been observed. Similarly, the proportion of residents who leave the central areas for other metropolitan destinations is annually decreasing. This paper aims to analyze the back-to-the-city movements in the largest Spanish metropolitan areas primarily from a geo-demographic perspective. The excellent temporal and geographic coverage of the Spanish Register of Residential Movements - a 100\% microdata dataset that includes each residential movement that has occurred in Spain and the migrant's demographic characteristics - enables the identification of residential mobility flows between the centre and the periphery, of their historical evolution, and of the demographic structure of the concerned migrants.

\section{Keywords}

Urban demography, re-urbanization, residential mobility, inner city, southern Europe. 


\section{Introduction ${ }^{2}$}

Spain's two largest central municipalities, Madrid and Barcelona, have recently experienced a remarkable period of population growth after the severe population decrease that was registered in the inner cities of these municipalities during the last quarter of the 20th century. This process has been widely repeated with some delay by the rest of Spain's major cities. Positive growth in Valencia has restarted after a remarkable population decrease during the 1990s. In Seville, demographic growth has become more intense, and in Bilbao, the population decrease observed since 1981 has recently ceased. Thus, Spain's largest metropolitan areas reflect the re-urbanization that other southern European cities, such as Rome, Milan, Turin and Marseille, are undergoing and that many other cities in central and northern Europe and the United States underwent during the last two decades of the 20th century.

This descriptive study aims to (i) integrate this new urban feature of the major Spanish inner cities in the classic framework of the urban development cycle and (ii) analyze the demographic components that are behind the population increase in Spanish inner cities. Regarding this last point and considering that natural growth rarely causes the population to increase in central areas, the study aims to answer the following questions. What is the effect of the settlement of international migrants on central-city population gains? Could we measure in terms of residential mobility whether suburban areas are less attractive to individuals who move from the central city and the central city more attractive to suburban movers? A preliminary examination of the data indicates a key role for international migration in the comeback. However, it should be questioned whether an increase in the attractiveness of the central areas has simultaneously emerged in the context of residential mobility and internal migration.

This paper analyzes the back-to-the-city movements in the largest Spanish metropolitan areas primarily from a geo-demographic perspective. The excellent temporal and geographic coverage of the Spanish Register of Residential Movements - a 100\% microdata dataset that includes each residential movement that has occurred in Spain and the migrant's demographic characteristics - enables the analysis of the territorial are-

2. This research was performed in the context of the $\mathrm{R}+\mathrm{D}$ project «Inmigración internacional y familia en España: Trayectorias de pareja en perspectiva transnacional» (CSO2011-24544), which is led by Dr. Albert Esteve Palos (PI). 
as of residential relation with the city center, the temporal evolution of the residential flows, and the demographic structure of the individuals who participate in them.

\section{The comeback of the central city: Theoretical background}

In the recent past, other southern European cities have experienced trends similar to those observed in Spain's major cities. Central Rome lost more than 200'000 inhabitants between 1981 and 2001 but recovered nearly the same number during the last decade. The inner cities of Milan, Turin and Florence have never reached again the population counted in 1971, but the population increase experienced during the recent years ends three decades of declines ${ }^{3}$. Marseille exhibits a similar pattern with a total population increase of $7 \%$ during the period 1999$2009^{4}$. Nevertheless, the population has continued to decrease in the major inner cities of Greece and Portugal.

Thus, the population increase in the urban cores of southern Europe reflects the processes that many other European and U.S. cities underwent during the last two decades of the 20th century. In the US, a large number of inner cities have experienced population growth since 1990 and particularly since 2000 (Frey, 2005). In the latter half of the 2000s, the population of cities and dense inner suburbs increased faster than that of most suburban rings (Frey, 2012). For Europe, the literature provides evidence of a population increase in the core of London, including the remarkable increase that has occurred in Inner London since the 1980s (Atkinson, 2000; Hall, Odgen, 2003), and in Paris, where a long period of dramatic decline ended during the 1980s (Odgen, Hall, 2000). In the Nordic countries, Stockholm's core experienced population increase already in the 1980s after two decades of substantial decrease (Nyström, 1992). Since then, center-city population growth in the central city has continued. More recent examples include population increase in the cores of major cities in Switzerland (Rérat, 2012), eastern Germany (Kabisch et al., 2009) and eastern European cities, such as Ljubljana (Buzar et al., 2007).

\footnotetext{
3. Istituto nazionale di statistica (ISTAT): $h t t p: / /$ demo.istat.it/.

4. Institut National de la Statistique et des Études Économiques (INSEE) : http:// www.insee.fr/fr/themes/detail.asp?ref_id=1139\&reg_id=5.
} 
These trends have been widely discussed, and falls into a highly accepted literature on re-urbanization, specifically, the return of the population to central city areas. This process has been linked to a new functional specialization of the inner city (Musterd, 2006) and the inner city's new economic, social and cultural renaissance (Cheshire, 2006; Storper, Manville, 2006; Lees, 2004). Re-urbanization is traditionally understood to be the fourth stage in the classic formulation of the urban development cycle (Van der Berg et al., 1982; Champion, 2001). This phase occurs after the periods of urbanization, suburbanization and counterurbanization and is defined by the increase in the population of urban cores. This stage reverses the dynamics of the two previous phases, during which the population growth of inner cities is assumed to be substantially lower than that observed in the suburban rings. In addition, the literature has examined the parallel processes that occur during the re-urbanization phase. One such process is gentrification, which is a transformation of urban neighborhoods that results in a change in the residential composition of these neighborhoods. Another process is the socio-demographic transformation of urban cores (typically linked to the second demographic transition), such as changes in living arrangements and household typologies (Lesthaeghe, 1995; Odgen, Hall, 2000). These processes are not treated in this study. Here, we focus on the quantitative dimension of re-urbanization, i.e., the analysis and decomposition of the migration flows and population balances that have made the population turnaround possible. In this sense, previous studies on European cities have indicated the key role that the settlement of international migrants in urban cores has played in the population reversal and the necessity of investigating the migration balances between urban cores and suburban rings (Champion, 2001; Golini, 2001; Buzar et al., 2007).

\section{Data and methods}

The small size of Spanish municipalities is important for this paper's development because it facilitates the identification of the urban core separately from the remainder of the metropolitan area. The central municipality of each province is understood as the central city, and the remaining provinces are used as a comparative measure of metropolitan areas. However, there are differences in the extension of these units, which must be considered in the analysis of the results. 
Five major cities are included in the study: Barcelona, Bilbao, Madrid, Seville and Valencia. Barcelona and Madrid are Spain's largest metropolitan areas. Their difference is remarkable compared with the other selected cities (Table 1). Although both provinces occupy a similar area and have analogous populations (approximately six million people in $8^{\prime} 000 \mathrm{~km}^{2}$ ), there are significant differences in the area occupied by both central municipalities. It must be considered that Barcelona's central municipality is six times smaller than Madrid. Nevertheless, the attributes that the literature assigns to the central cities of metropolitan areas are clearly distinguished in both units. Valencia and Seville have similar characteristics in terms of the area and the population of the central municipality and the remainder of the province. In both cases, the central municipalities occupy an area slightly larger than Barcelona's and far smaller than Madrid. Bilbao (the capital of Biscay Province) is included in this research primarily because of the small area of the central municipality. Consequently, in this case, we may expect to observe stronger processes related to centrality.

TABLE 1 Geographic characteristics of central municipalities and provinces

\begin{tabular}{|l|c|r|r|r|r|r|}
\hline & \multicolumn{3}{|c}{ Central municipality } & \multicolumn{3}{c|}{ Province (metropolitan area) } \\
\hline Population & \multicolumn{1}{|c|}{$\mathrm{Km}^{2}$} & \multicolumn{1}{c|}{ Density } & Population & \multicolumn{1}{c|}{$\mathrm{Km}^{2}$} & Density \\
\hline Barcelona & $1^{\prime} 619^{\prime} 337$ & 98.21 & $16^{\prime} 488.51$ & $5^{\prime} 511^{\prime} 147$ & $7^{\prime} 728.17$ & 713.12 \\
\hline Madrid & $3^{\prime} 273^{\prime} 049$ & 605.77 & $5^{\prime} 403.12$ & $6^{\prime} 458^{\prime} 684$ & $8^{\prime} 027.69$ & 804.55 \\
\hline Seville & $704^{\prime} 198$ & 141.31 & $4^{\prime} 983.36$ & $1^{\prime} 917^{\prime} 097$ & $14^{\prime} 036.09$ & 136.58 \\
\hline Valencia & $809^{\prime} 267$ & 134.63 & $6^{\prime} 011.05$ & $2^{\prime} 581^{\prime} 147$ & $10^{\prime} 806.09$ & 238.86 \\
\hline Biscay & $353^{\prime} 187$ & 41.31 & $8^{\prime} 549.67$ & $1^{\prime} 153^{\prime} 724$ & $2^{\prime} 217.28$ & 520.33 \\
\hline
\end{tabular}

Source: National Statistical Institute of Spain. Populations updated 01/01/2010.

The study primarily relies on data from the Spanish Register of Residential Mobility. This information source registers every residential movement that crosses a municipal border ${ }^{5}$ in Spain. That is, the register is a flow record, in which the unit of recollection is the movement and not the mover (one person may appear more than once per year). Individuals who reside in Spain must register their current place of residence by law. Consequently, any change in the place of residence must be reported. Moreover, health and school public systems require individuals to be registered in the municipality of attendance. However, the register relies

5. Today, there are 8'117 municipalities in Spain, with an average area of $62.2 \mathrm{~km}^{2}$. 
on the self-declaration of individuals, which results in an underestimation of the number of residential movements. This underestimation is a limitation of this information source. However, considering that we are only analyzing internal migration, there had not been remarkable changes in the registering methods during the analyzed period that affect the likelihood that an individual will register a change of residence (Ródenas, Martí, 2006; 2010). This point is key to the validation of the trends observed in our analysis.

In addition to the municipalities of origin and destination, the microdata dataset provides demographic information on the individual who moves. The wide coverage of this source enables this study to analyze the territorial relationships of the urban cores in the context of re-urbanization, its temporal variations, and the demographic structure of individuals who participate in the residential flows of the central city involved. Using this data source, two primary movement types have been identified. On the one hand, we analyze the residential movements that depart the central cities for elsewhere in the province and Spain. These movements are grouped in different categories according to the straight-line distance from the urban core. On the other hand, the movements that depart from the rest of the province for the central municipality are grouped under the same category.

The gross migraproduction rate (GMR) has been calculated to measure the intensity of the different types of residential flow and their evolution over the studied period. The GMR, which was introduced by Rogers (Rogers, 1975), indicates the number of residential movements that an individual would experience during the life course if the current rates remained stable throughout his or her life. The elaboration of this indicator is identical to the total fertility rate (TFR). The GMR has been decomposed by the destination or the origin.

The GMR's general formulation is as follows:

$$
G M R=5 \sum_{x} m(x)
$$

where $\mathrm{m}(\mathrm{x})$ are age-specific residential mobility rates.

\section{A new stage in the urban cycle of Spain's major cities?}

In recent decades, Spain's urban centers have experienced demographic processes of opposite sign. The concentration of population in the urban 
cores that characterized the Spanish urban and demographic systems after the Industrial Revolution was followed by an intense period of suburbanization and a population decrease in urban centers. This phase has been recently interrupted by the demographic recovery of the central areas in most major Spanish cities.

The demographic concentration in urban centers was the predominant process in the largest Spanish cities until 1970. In the case of the two most-populated inner cities, Barcelona and Madrid, a remarkable increase in the number of inhabitants and households is observed for the period 1950-1970 (Figure 1). In Barcelona, the relative growth of the two analyzed variables during the 1950s was higher than in the 1960s, whereas in Madrid, the peak was reached during the 1960s. This difference was caused by the smaller area of Barcelona's central municipality, which anticipated the saturation of its urban fabric and the subsequent arrival of its population peak (Cabré, Muñoz, 1997). The remaining large Spanish central cities, which are significantly less populated than Barcelona and Madrid, experienced their urban explosion during the 1960s and the 1970s. This period also witnessed the formation and extension of the metropolitan areas in Spain, with the growth of the functional areas and the consolidation of the metropolitan networks (Nel-lo, 2004). Thus, the areas located close to the inner cities also experienced an intense increase in population and number of households. The demographic and urban growth of this period is primarily explained by intraand inter-regional migrations, which are associated with the labor market and the transfer of the active population from the primary sector to industry, construction and services (Nel·lo, 2004; Terán, 1999).

Clear evidence of urban maturity and saturation were identified in Barcelona and Madrid during the 1970s, when the urban cores experienced a low increase in population. Moreover, this weak increase was exclusively the consequence of a high natural growth that compensated the negative net migration that urban cores began to register (López-Gay, 2008). Inter-regional migratory flows stopped, and demographic scattering, the urban dispersion and the expansion of the functional areas emerged as the primary processes that affected the demographics of the metropolitan areas (Recaño, 2004). Residential mobility became the key to explaining the demographic and migratory dynamics of Spanish metropolitan areas (Módenes, 1998). Adults and young adults (and their families) in search of a new residence in the suburban rings was the most common profile of the individuals who participated in the flows. These processes occurred at different times in Spain because the cities that started the processes of population concentration earlier were the 
first to register demographic losses. To explain the negative demographic growth of the central areas during the last decades of the 20th century, the following elements should be considered: i) pure demographic elements, i.e., the arrival at the age of leaving home of the baby-boomer generation (those born between 1960 and 1975), which significantly increased the housing demand in the urban areas (particularly the center: ii) the revalorization of the suburban spaces by the relocalization of economic activity, the expansion of the transportation infrastructure, or new residential patterns, which resulted a higher value being placed on a dwelling's characteristics and environment; and iii) the housing market, which presented cheaper prices in the most distant rings, and the increasing acceptance of longer commutes (López-Gay, 2008). In all of our studied cases, the relative growth of the population and the number of households in the metropolitan rings between 1981 and 2001 were always higher than in the central city. For Barcelona and Madrid, the metropolitan extension to the second ring can be clearly perceived after 1981. Although the suburbanization processes were intense and moved population to distant metropolitan locations, Spain's major metropolitan areas did not experience an authentic counterurbanization phase because the overall population of the metropolitan territories never decreased. However, in the 1980s and early 1990s, the population growth of the studied metropolitan areas was nearly zero. This pattern contrasts with the dynamics of many western European metropolitan areas, which experienced a population decrease during the 1970s and 1980s (Cheshire, Hay, 1989).

The evolution of the number of households and their size is essential to understand the process of urban dispersion from a demographic perspective. The decrease in the population registered after 1981 in the central cities has never corresponded in a decrease of the total number of household, which remained stable during this period. The inability of the central areas to increase the housing supply at the same speed as the decrease in the household size generated a new housing demand for metropolitan rings. This phenomenon should be considered in the attempt to understand the Spanish suburbanization processes. The arrival at the age of leaving home of the baby boomers who resided in the urban cores, with the subsequent creation of new households that were not balanced by a decrease in households at the top of the pyramid, has played a major role in this process (López-Gay, Mulder, 2012). 
FIGURE 1 Total population and number of households in the provinces of Barcelona, Madrid, Seville, Valencia and Biscay by distance to the central municipality, 1950-2001
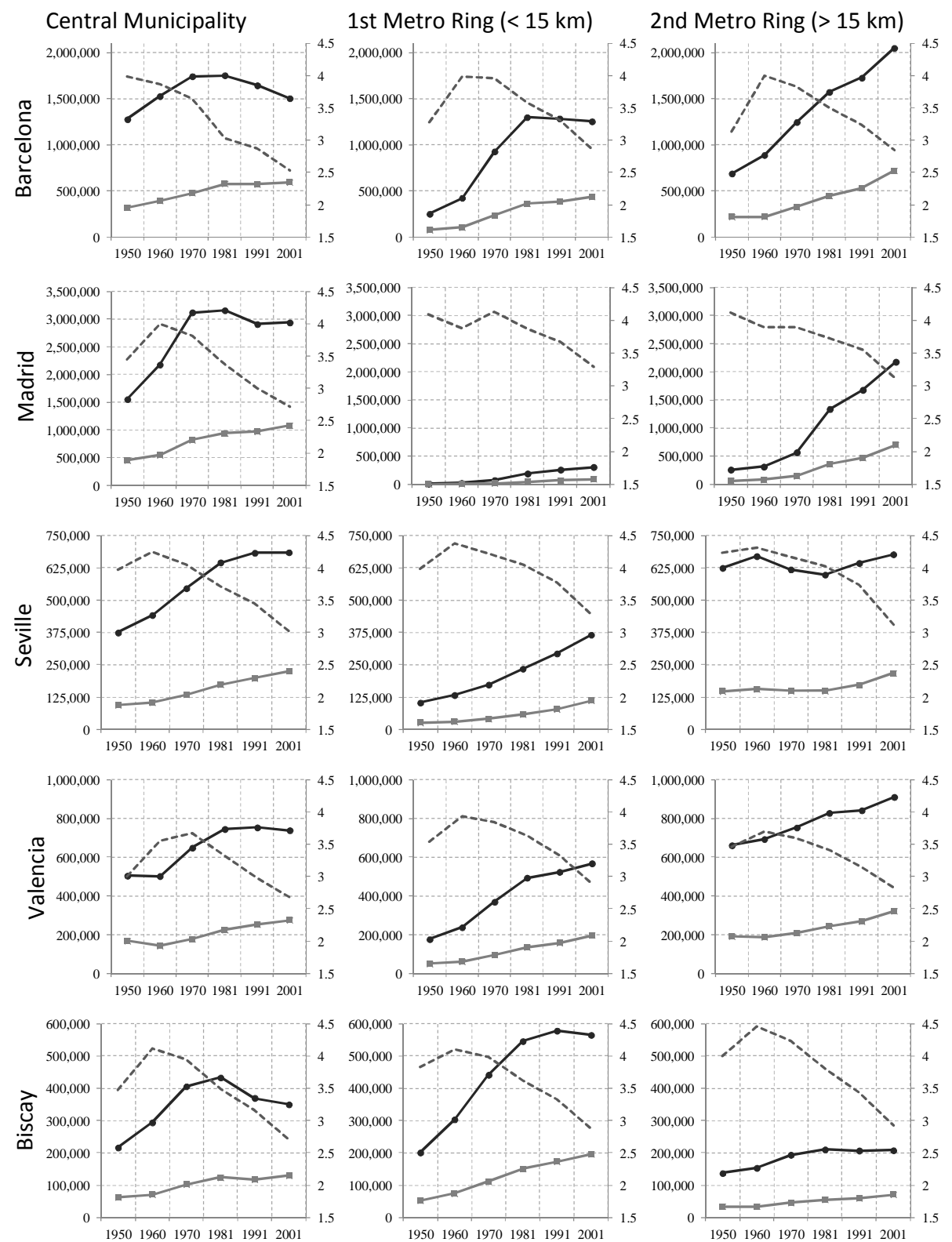

$\longrightarrow$ Population $\longrightarrow$ Households --- Household size (right axis)

Source: Population and household censuses, 1950-2001. 
The total population of the central municipalities of Barcelona and Madrid reached its lowest levels in the late 1990s. In the case of Barcelona, the inner city lost more than 250'000 inhabitants in 20 years, and the population decreased to less than 1.5 million. In Madrid, the decrease was similar in absolute numbers, and the total population was less than 2.9 million at the end of the 20th century. Valencia's central municipality also experienced a period of population decrease during the 1990s, and Seville interrupted its demographic growth despite having a large natural balance. The small municipality of Bilbao reached its urban and demographic saturation during the 1970s. Since then, Bilbao's total population has continually decreased. However, a new period of population stabilization has recently commenced.

FIGURE 2 Total population in the selected central municipalities:

Barcelona, Bilbao, Madrid, Seville and Zaragoza, 1991-2010


Source: Population census (1991) and the Register of Population (1996-2010). 
The largest population increase during the last decade was registered in Barcelona, Madrid and Valencia (Figure 2). The 2010 update of the Spanish Register of Population indicates that the total population of Barcelona increased by nearly 150'000 persons. Madrid and Valencia reached a new maximum value. The large extension of these central municipalities compared with Barcelona has facilitated this increase, and a substantial number of new housing units have been recently added to the urban fabric in Madrid and Valencia. Seville and Bilbao have not experienced the same increase in population, and their overall numbers have remained approximately unchanged during the last decade.

\section{Demographic components of the population growth in central cities}

Which demographic component explains this last phase of population growth in Spain's primary central municipalities? After decomposing the demographic growth ${ }^{6}$ of the period 1998-2010, there is a clear answer to this question: four out of the five cities (Barcelona, Bilbao, Madrid and Valencia) would not have experienced a population increase without the contribution of international migration (Figure 3). Only the municipality of Seville does not exhibit such a significant contribution of international migration. In this case, the high rates of natural growth are the reason why the city did not experience a substantial loss of population. Seville is the only case in which the natural growth acquires high positive values. In other cities, such as Barcelona, Bilbao or Valencia, the natural growth is negative or slightly positive.

This exercise enables the identification of another element that is important to understanding the demographic dynamic of the central cities during the last decade. That is, the total population growth of the central cities hides a negative internal net migration. Although the analyzed cities have gained population in recent years, they continue to exhibit a population decrease as a result of internal migration. All of the analyzed cities display a negative internal net migration that is particularly noticeable in relation to the municipalities of their own metropolitan are-

6. The factorization of the demographic components was developed using the basic demographic equation. In this case, and considering that the Vital Statistics register and the Register of Residential Mobility offer a high degree of reliability, the difference between the total growth of the municipality and the sum of the natural increase and the internal net migration has been assigned to international net migration. 
as. Thus, the results indicate that suburbanization processes continued in Spain's largest cities during most of the 2000s.

FIGURE 3 Demographic components of population growth in central cities. Annual average, 1998-2010

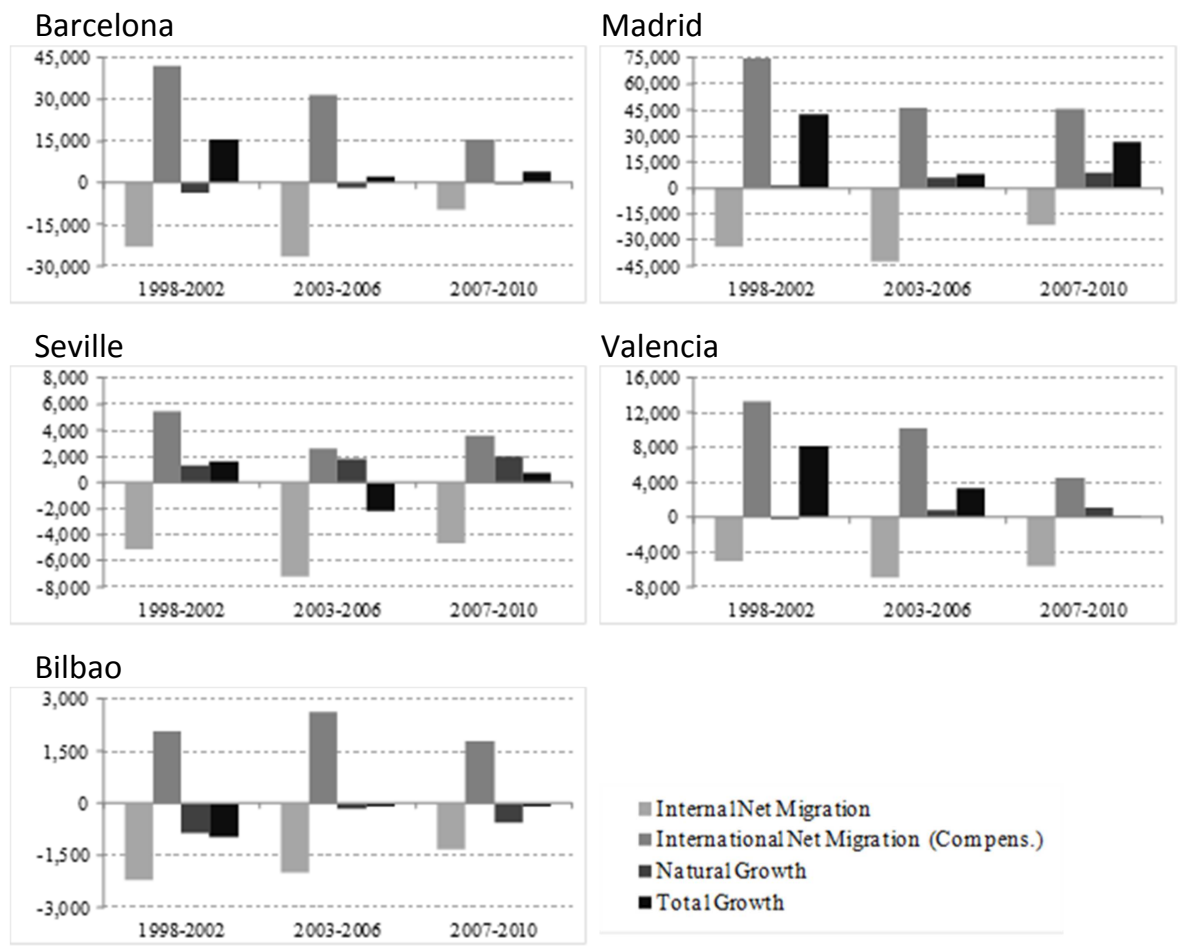

Source: Register of the Population, Register of Residential Mobility, and Vital Statistics (1998-2010).

However, in all of the analyzed cities, the last period's negative internal net migration exhibits a substantial decrease compared with the values reached during the previous periods. The annual analysis - which includes a territorial approach - lends emphasis to these arguments (Figure 4). In general, the negative migratory balance of the central cities is not as intense as during the mid-2000s. This relation became particularly clear in the territorial relation of the central cities with the municipalities of their own province.

Barcelona is one case in which the negative net migration has significantly decreased. On the one hand, the absolute number of residential movements generated in the central city with a destination in the second metropolitan ring has exhibited a continuous decrease since 2003. 
On the other hand, the number of residential changes moving into the central cities from the first and second metropolitan rings displays a clear increasing trend. As a consequence of these divergent trends between the two flows, internal net migration has been remarkably reduced. In 2003, the central city of Barcelona lost 25'000 individuals in the residential relation with the rest of its province. In 2010, the city only lost 6'500 individuals in this residential relation, which represents one fourth of the 2003 value. The reduction of the negative net migration includes both Spanish and foreign nationals. This latter also constituted an important example of metropolitan dispersion during the first half of the decade (Bayona, López Gay, 2011), which lost intensity in the most recent years. In the last observed year, the net migration of foreign nationals has been approximately zero.

In Madrid, it seems clear that there has been a moderate decrease in the negative net migration since 2006. In this case, because of the central municipality's large area, most residential flows occur in connection with the municipalities located more than $15 \mathrm{~km}$ distant. The number of departures toward these areas has decreased from more than $55^{\prime} 000$ movements per year to $45^{\prime} 000$ since 2006 , whereas the number of arrivals from the same municipalities has remained steady. In Valencia, the number of movements leaving the central city to the province has decreased from $22^{\prime} 000$ in 2006 to $17^{\prime} 000$ in 2010 . Reproducing the pattern of the largest cities, an increase has been experienced in the flows of individuals who move into the urban core: from 10'000 in 2005 to $14^{\prime} 000$ in 2010. In Valencia, the decrease has been particularly marked in the migratory relation with the closest municipalities. Seville demonstrates a similar pattern. That is, the number of residential movements generated in the urban cores toward the metropolitan area has significantly decreased since 2006, whereas the arrivals from the same areas exhibit a slight increase. Bilbao is the only city among the cities studied here that does not exhibit the same pattern. In this case, both the arrivals and departures to or from the central city have increased during the last years, and the net migration seems to have remained stable.

The absolute number of movements arriving in the central cities with an origin in other Spanish provinces also increased during the second half of the decade. As a consequence, the net migratory balance in the relation with the rest of Spain has become positive in all of the studied cities. In all cities but Bilbao, the movement trends of Spanish and foreign nationals have contributed to this new scenario. 
Figure 4 Evolution of the internal net migration (NMigr) of the central municipalities by movement type, 1998-2010

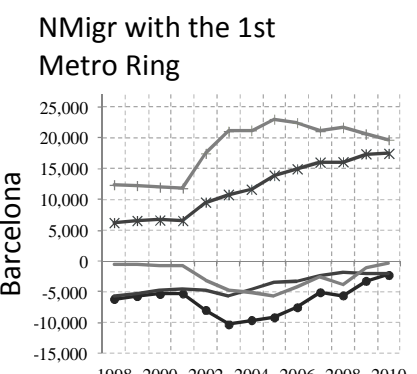

NMigr with the 2nd Metro Ring

1998200020022004200620082010
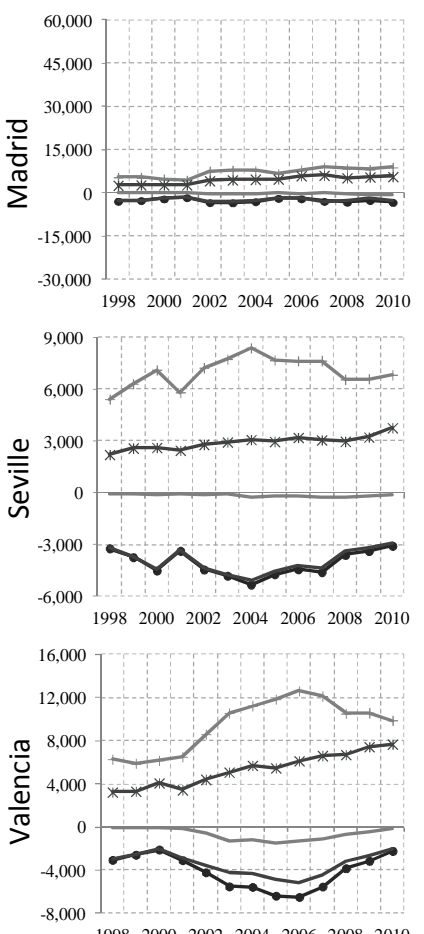

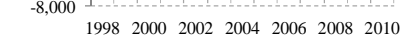

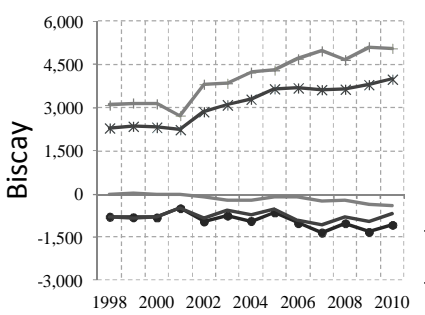

1998200020022004200620082010



Source: Register of Internal Migration, 1998-2010.
NMigr with the rest of Spain
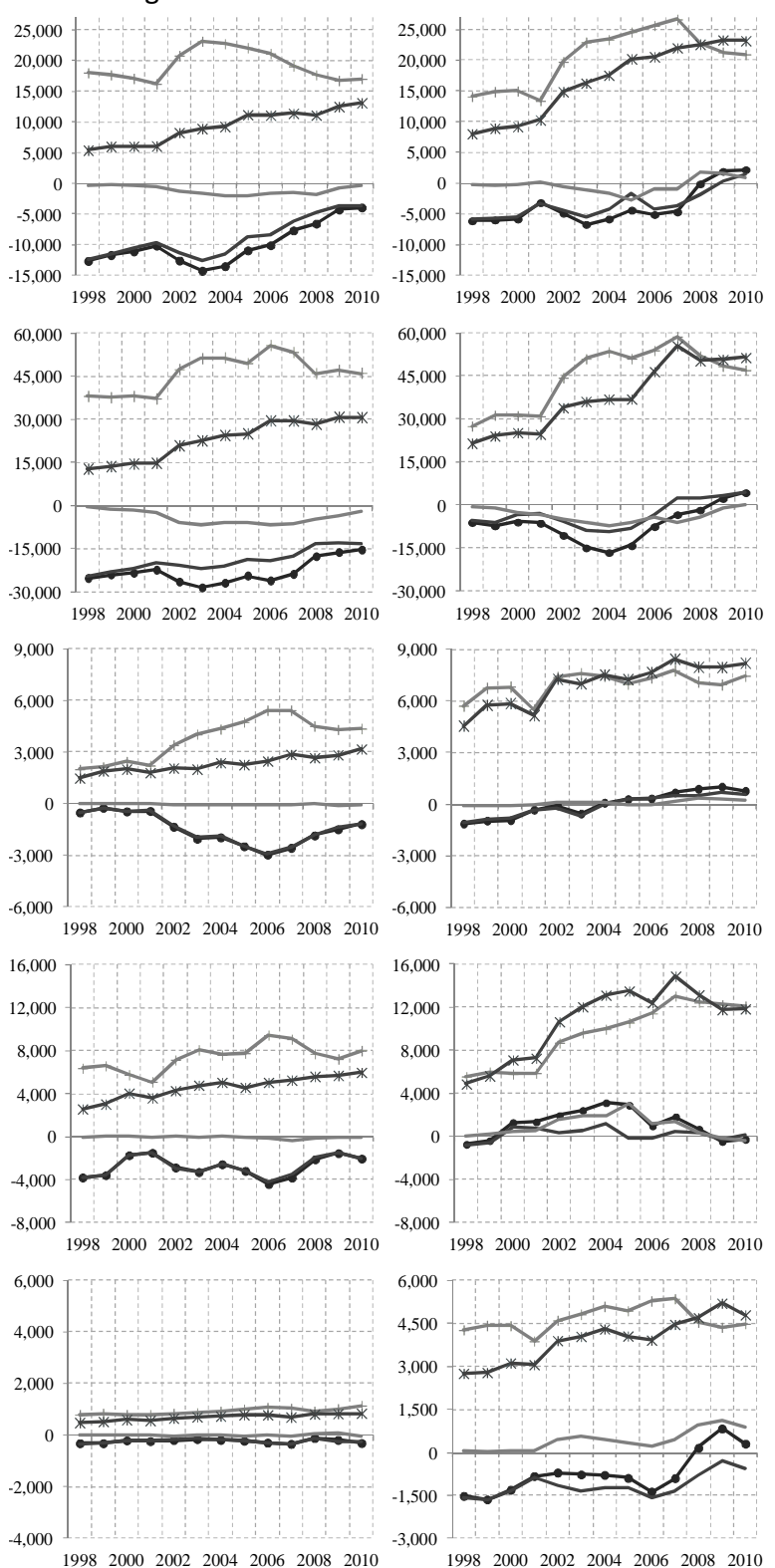

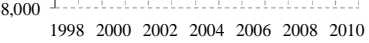

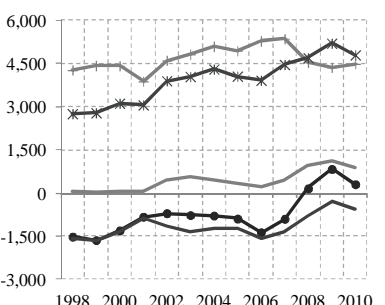

3,000 1998200020022004200620082010 - NMigr(Foreign Nationals) 


\section{Intensity and demographic structure of the migratory flows that involve the central cities}

Thus, the largest Spanish central cities have been a priority destination of international migratory flows. Moreover, observing the results of the previous section, we could ask whether the attractiveness of the central areas has also increased in the context of the internal migration and the residential mobility during the last years. The previous analysis of the absolute values of the residential flows seems to indicate this new role of the central areas as a more common destination for metropolitan residents. To better answer this question (and to move from absolute numbers to a synthetic indicator that controls for age), the gross migraproduction rate (GMR) has been calculated by destination and origin. The GMR is an accurate indicator with which to compare the evolution of the intensity of migration during the last years (Figure 5).

A global assessment of these results reveals two divergent trends. In most cases, the residential movements that originated in the central city and were destined for the rest of the metropolitan areas significantly lost intensity in the last years, whereas the residential movements that originated in the suburban areas and were destined for the central cities either increased in intensity or did not decrease.

Barcelona is a good example of this process. The GMR of the residential movements that originated in the central city and were destined for the metropolitan municipalities located beyond the $10 \mathrm{~km}$ ring was $1.30 \mathrm{in}$ 2003. Seven years later, in 2010 , the indicator exhibits a $30 \%$ decrease. This decrease has been registered in particular in the flows toward the farther metropolitan locations. However, the residential movements that originated in the rest of the province and were destined for the central city experienced a 50\% increase in the same period (from 1.26 to 1.86). Valencia is similar. A decrease in the intensity of the movements leaving the central city (primarily since 2006) can be observed, which has been accompanied by an increase in the intensity of the residential flows moving into the central city from the suburban areas. In this case, the GMR changed from 1.08 in 1998 to 1.97 in 2010.

Madrid's patterns are not as revealing as those of Barcelona or Valencia. On the one hand, there has been a clear decrease in the flows moving to the farther metropolitan rings (the GMR of the residential flows leaving the central city and destined for the farther suburbs changed from 1.10 in 2006 to 0.80 in 2010). However, the intensity of the movements with destinations in the nearest municipalities has remained stable in the last 
years. The intensity of the movements with destinations in the central city that originate in the metropolitan suburbs was higher during the second half of the decade. However, the differences are not as remarkable as in the previous two cases. Finally, Bilbao and Seville do not display a decrease in the movements that originate in the central city, although a slight increase in the attractiveness of the central areas could be ascertained.

FIGURE 5 Intensity of the residential mobility (moving out of or into the central municipality) by movement type, Gross Migraproduction Rate (GMR), 1998-2010
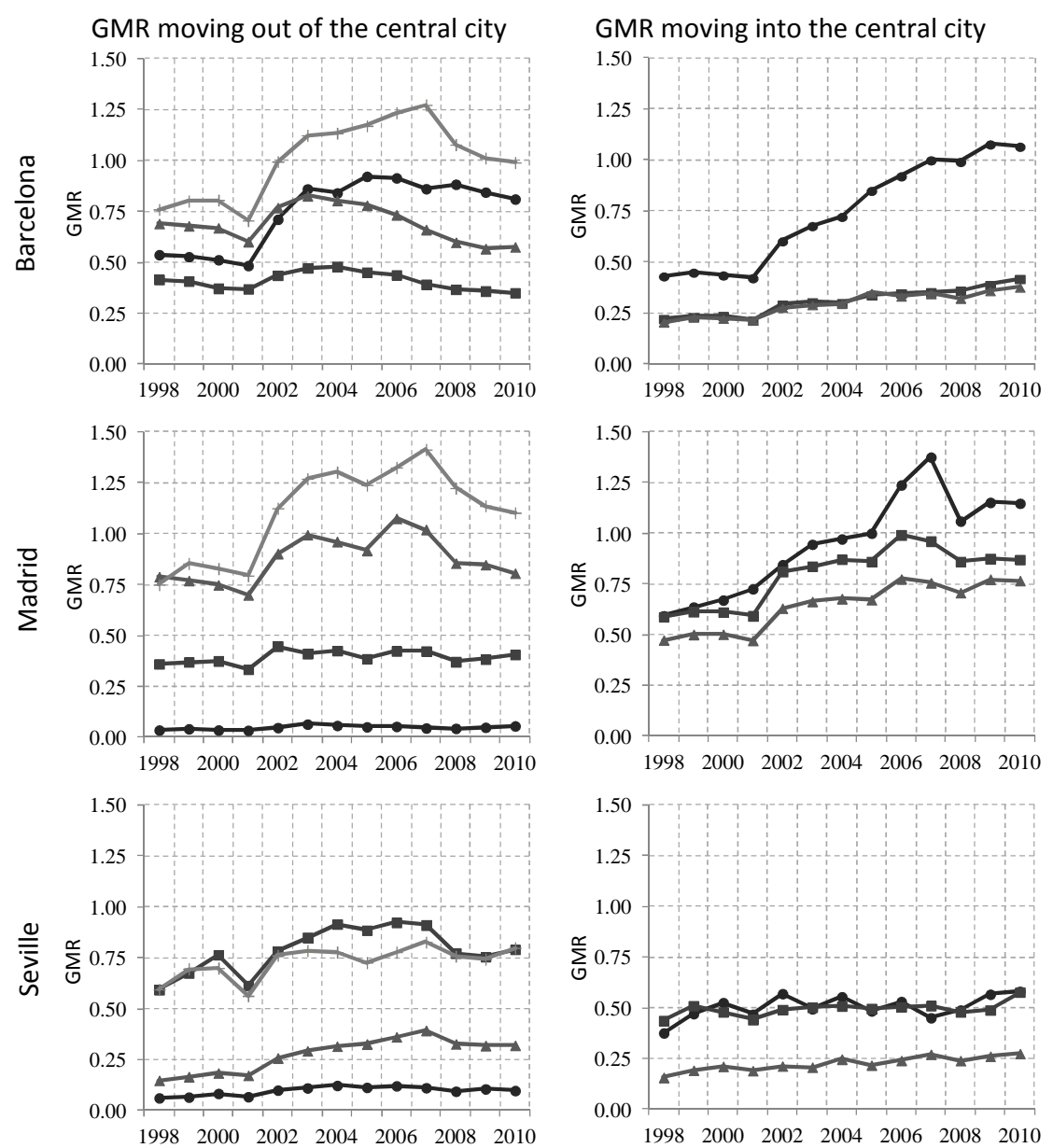

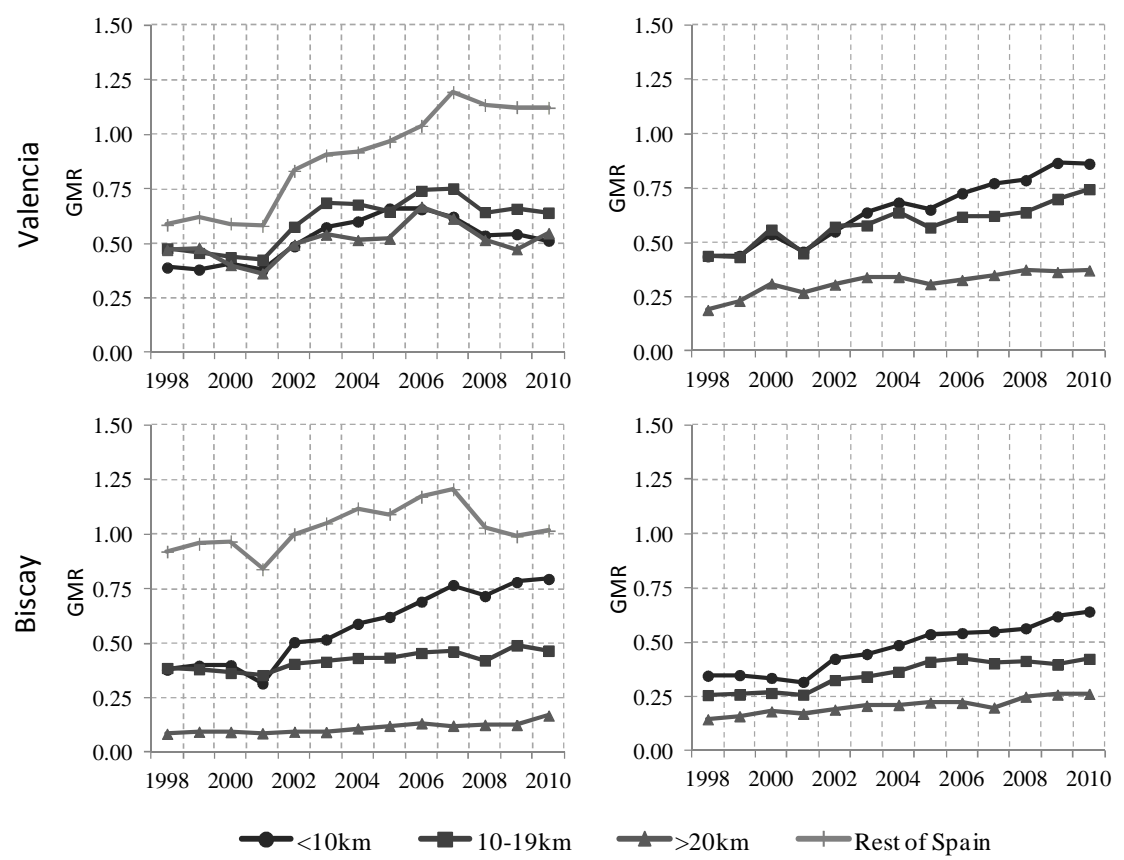

Source: Register of Residential Mobility and Register of Population, 1998-2010.

The proportion of residential changes moving within the central city has been added to this analysis to evaluate the decrease in the flows that move out of the urban core (Figure 6). By including the movements that occur within the central city, we can answer the following questions. Is the decrease in suburban movements a consequence of a decrease in the intensity of the total mobility generated in the urban core? In contrast, has the inner city improved its attractiveness and capacity to retain the residential mobility that is generated in the central areas? To answer these questions, the registers of the residential movements within the central city are required. This movement type is not included in the Spanish Register of Internal Migration because no municipal borders are crossed. The availability of these data depends on each city council. Barcelona, Madrid and Valencia publish this information by resident citizenship, but not Seville and Bilbao. A certain degree of error is assumed when two different sources are combined to create an indicator. However, there is no evidence that the quality of each data type has substantially changed during the analyzed period. Thus, strong trends over time should be interpreted to be meaningful, which is the case for Barcelona for Spanish and foreign nationals. In 2004, nearly $40 \%$ of the movements generated by Spanish nationals in the central city crossed the mu- 
nicipal border (only in the context of movements within the province). In 2010 , fewer than $30 \%$ of such movements crossed this border. Similarly, foreign nationals, are more willing to remain in the central city when changing residence. The series in Madrid and Valencia are shorter. However, an increase in the intra-municipal movements is also observed in the most recent years.

FIGURE 6 Proportion of residential movements that remain in the central municipality (out of all the flows that move within the province) by citizenship, 2000-2010

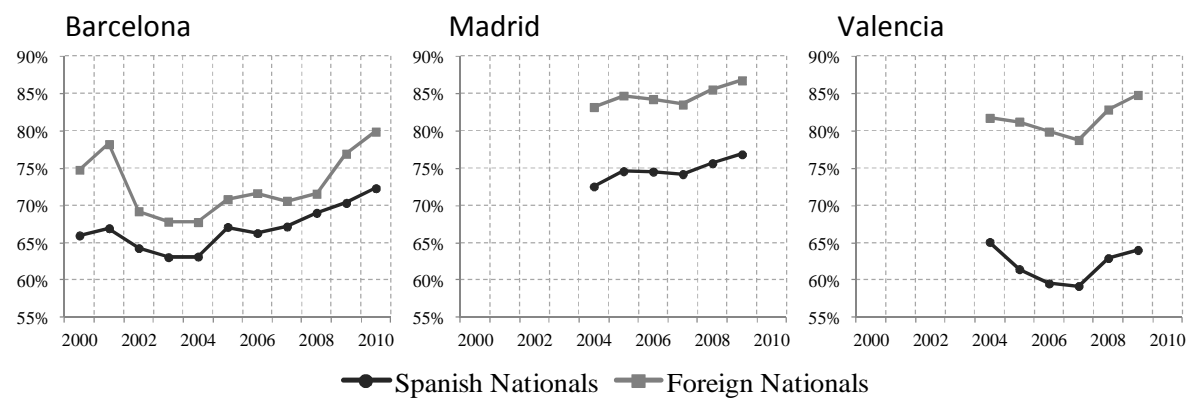

Source: Register of Residential Mobility and Municipal Register of Intra-municipal Movements, 20002010.

The shape of the curve that represents the age and sex characteristics of the residential flows aligns with the classic curve of residential mobility (Figure 7). In a context of low mobility compared with western and northern European countries, the peaks of higher intensity are associated with the primary changes in individual and familial life cycles (Clark, Onaka, 1982; Módenes, 1998). Most movements occur at household formation ages, which in Spain are experienced relatively later. This peak is followed by a period of higher residential stability.

However, careful examination reveals differences in the curves for each movement type. Are the age and sex characteristics of the individuals who participate in the residential flows that originate in the inner city identical to the demographic characteristics of the individuals who move into the city center from the suburbs? Are we discussing different profiles that respond to different residential strategies? A preliminary examination of the residential mobility curves of the flows that originate in the central cities reveals the oldest age of the individuals who move to areas farther from the metropolitan area. In all capital cities but Vale- 
FIGURE 7 Residential mobility rates (\%) of individuals who move into or out of the central cities, 2006-2010

Moving out of the central municipality



Barcelona - WOMEN

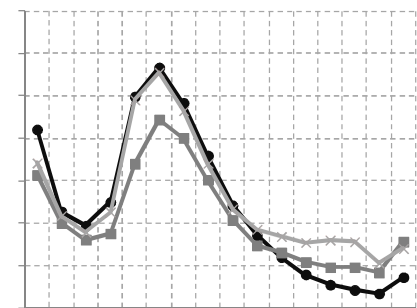

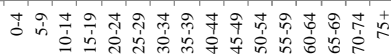

Madrid - MEN

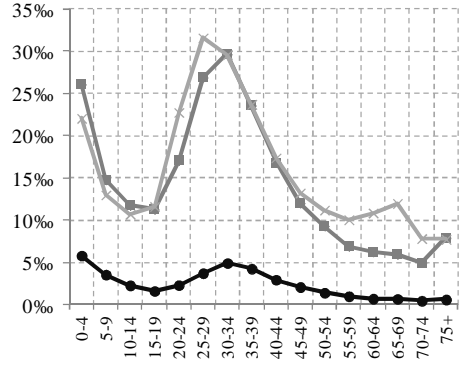

Madrid - WOMEN

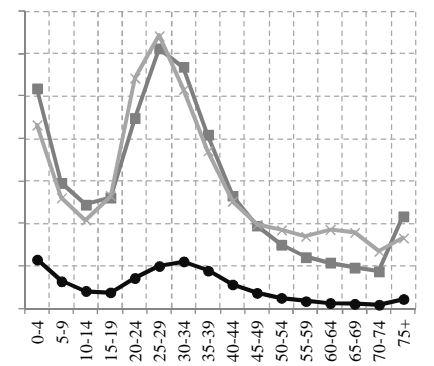

Moving into the central municipality


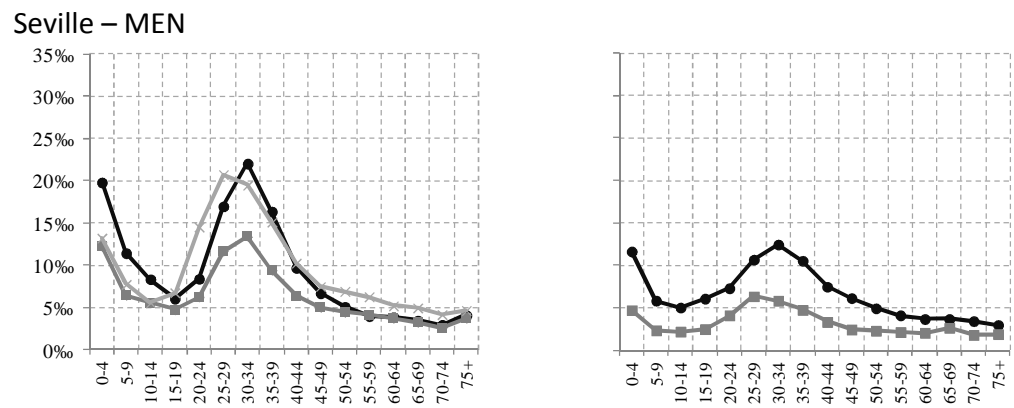

Seville-WOMEN
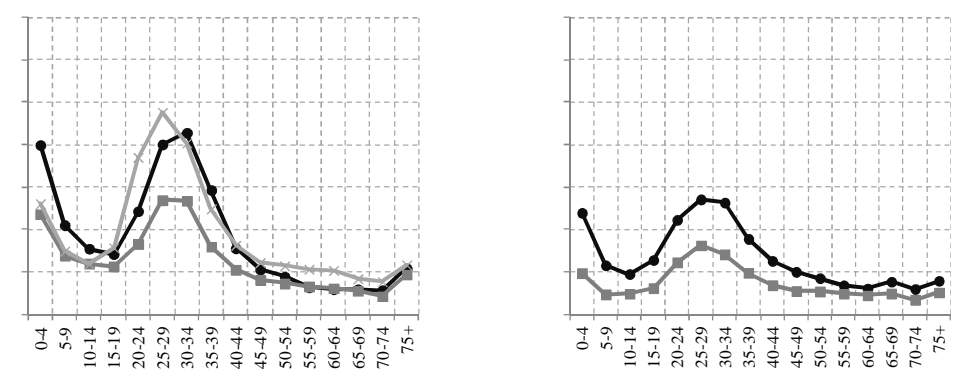

Valencia-MEN
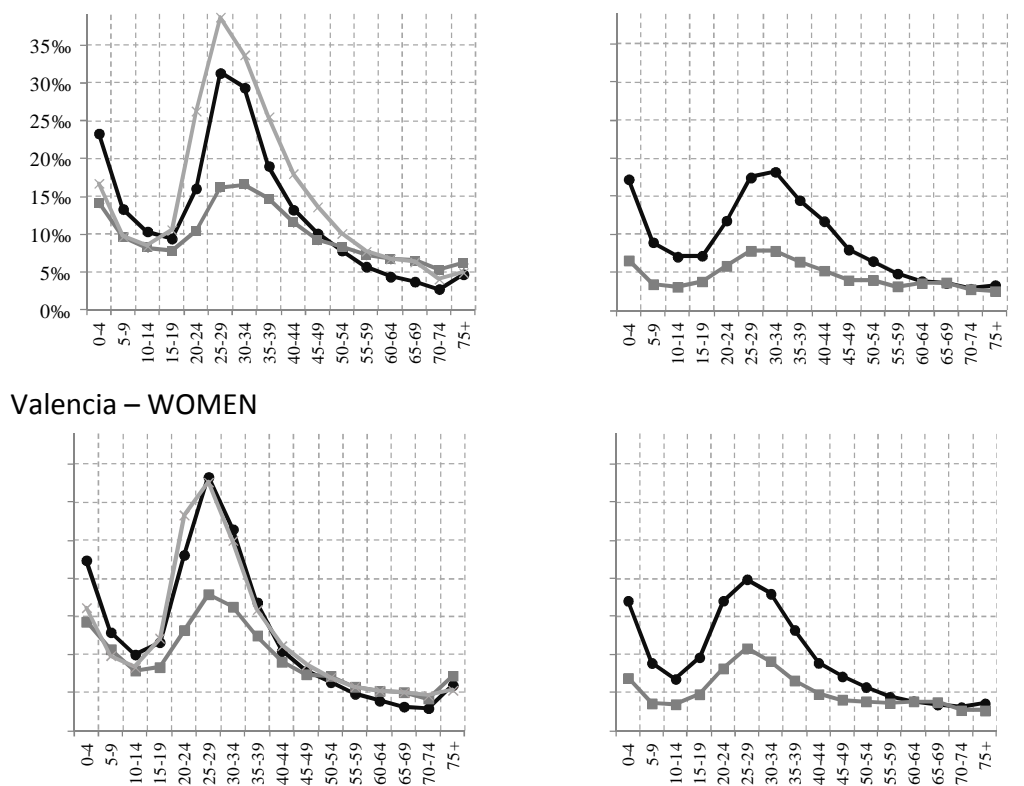

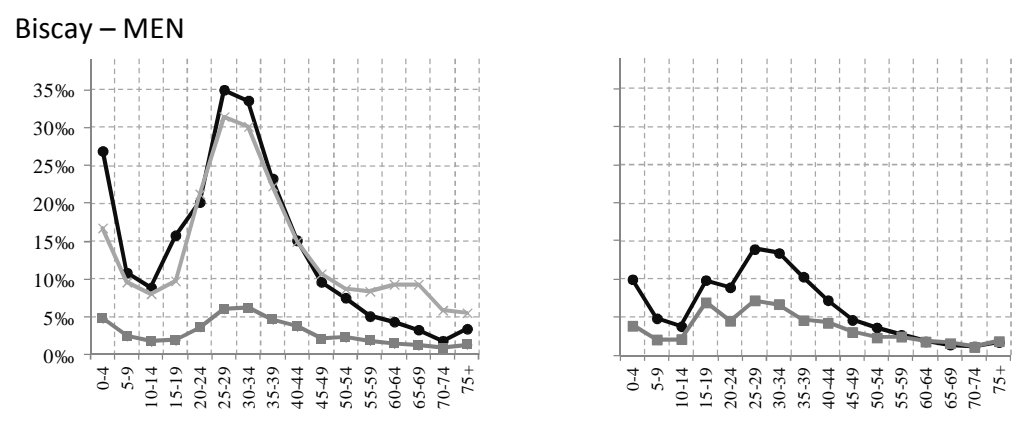

Bisacay - WOMEN


Source: Register of Residential Mobility and Register of Population, 2006-2010.

cia, the 30-to-34-year age group among men is the modal age in the movements that are destined for the farther municipalities of the metropolitan area. Residential movements from the urban cores to closer locations typically exhibit a younger age characteristic in all of the studied cities. There are no significant differences between men and women in this type of residential movement except the earlier age at which women move.

As expected after reviewing the development of the gross migraproduction rates, the intensity of the residential movements that originate in the metropolitan municipalities and are destined for the central cities does not reach the levels of the movements leaving the urban cores. However, in Barcelona and Madrid, the intensity of the residential flows generated in the nearest municipalities is remarkable. Generally, the shape of the curve of the residential flows that move into the city center does not exhibit the same concentration in groups associated with the age of leaving home. Thus, it seems clear that the decision to include central spaces in the residential strategies of the metropolitan residents can be made for a wide range of age groups. The case of Madrid and Valencia males is illustrative. Residential rates for individuals who move from the suburbs to the central city are higher in the 40-to-44-year age 
group than in the 20-to-24-year group. The attractiveness of central spaces seems to transcend the age group, particularly among men.

\section{Conclusions. The future of Spain's inner cities: Toward the inflexion of the internal net migration's sign?}

The arrival and settlement of foreign nationals in the urban centers has played a major role in the population increase in the largest central Spanish municipalities after many years of population decrease. This research has demonstrated that the population increase in the central cities continues to hide a negative net migration in relation to the metropolitan areas of these cities. However, signs of a recent recovery in the attractiveness exercised by the central areas were observed. This trend converges with the re-urbanization processes experienced in many mature European and North American cities during recent decades, which correspond to the final phase of the classic formulation of the urban development cycle.

In most of the Spanish metropolitan areas analyzed in this study, a significant increase in the intensity of the movements with a destination in the central city was registered for the second half of the last decade. Similarly, leaving the city movements have exhibited a decrease in intensity in most of the inner cities. Thus, for the first time in many years, the residential mobility trends of Barcelona and Madrid suggest that the negative balance between the central city and the remainder of the metropolitan area may not be permanent However, this new scenario may not occur immediately, at least in the case of Madrid, where the decrease in population as a result of internal migration remains remarkable.

The end of the migratory negative balance would mean the end of a period of more than 50 years during which the central cities studied here have lost population in favor of their metropolitan areas. The moment seems favorable to achieve this milestone. Vinuesa (2005) notes the effect of the aging of central city households on the housing supply. Spanish central cities exhibit a singular accumulation of households at the top of the pyramid, which is expected to disappear in the coming years. Blanes and Menacho (2007) announced a progressive reduction of the net generation of households in Barcelona as a result of the age structure of the city's population. According to their projections, at the end of the 2010s, a larger number of households will disappear as a result of mortality than households will be created in the city as an effect of de- 
mographic structure. This would be the first time this phenomenon has occurred in the contemporary history of Barcelona under these circumstances. There is no doubt that the arrival of remarkably small generations (born after 1980) at household formation ages combined with the disappearance of households at the top of the age pyramid will reduce the stress of the housing market in central locations and introduce changes in the metropolitan residential dynamics. In addition, the results of this research suggest that a remarkable number of residents who were compelled to leave the central city in previous years may consider moving back. The future participation of foreign nationals in this residential mobility will also play a major role in this process, as will the effect of the economic crisis on the housing market (by enhancing renting as an alternative to home ownership for the first time in recent decades) and the residential strategies of the population.

\section{References}

AtKInson R. (2000), "Measuring Gentrification and Displacement in Greater London», Urban Studies, 37 (1), pp.149-165, http://dx.doi.org/10.1080/ 0042098002339.

BAYONA J., LóPEZ-GAY A. (2011), «Concentración, segregación y movilidad residencial de los extranjeros en Barcelona», Documents d'Anàlisi Geogràfica, 57 (3), pp. 381412.

Berg L. V. D., Drewett R., KlaAsen L. H., Rossi A., Vijverberg C. H. T. (1982), Urban Europe: A Study of Growth and Decline, Oxford, Pergamon Press.

Blanes A., Menacho T. (2007), «Projeccions de població i llars dels municipis del Pla Estratègic Metropolità i districtes de la ciutat de Barcelona», Llibre blanc de l'habitatge a Barcelona, A. COSTAS (ed).

Buzar S., Odgen P., Hall R., HaAse A., Kabisch S., Steinfilmrer A. (2007), "Splintering Urban Populations: Emergent Landscapes of Reuranisation in Four European Cities», Urban Studies, 44 (4), pp.651-677, http://dx.doi.org/10.1080/ 00420980601185544.

CABRÉ A., Muñoz F. M. (1997), «Evolució demogràfica. La població de Barcelona des de 1930 a 1996», Història de Barcelona, J. SOBREQUÉs (ed), Barcelona, Enciclopèdia Catalana, 8, pp. 73-122.

Champion T. (2001), "Urbanization, Suburbanization, Counterurbanization and Reurbanization», Handbook of Urban Studies, 160, http://dx.doi.org/10.4135/ 9781848608375.n9. 
CheshiRe P. (2006), «Resurgent Cities, Urban Myths and Policy Hubris: What we Need to Know», Urban Studies, 43 (8), pp. 1 231-1 246, http://dx.doi.org/10.1080/ 00420980600775600.

CheshiRe P., Hay D. (1989), Urban Problems in Western Europe. An Economic Analysis, Unwin Hyman, Cambridge, 271p.

Clark W. A. V., ONAKA J. (1983), "Life Cycle and Housing Adjustment as Explanations of Residential Mobility», Urban Studies, 20, pp. 47-57, http://dx.doi.org/10.1080/ 00420988320080041.

FreY W. H. (2005), Metro America in the New Century: Metropolitan and Central City Demographic Shifts since 2000, Washington D. C., The Brookings Institution, Living Cities Census Series.

FreY W. H. (2012), Population Growth in Metro America since 1980: Putting the Volatile 2000s in Perspective, Washington D. C., The Brookings Institution, Metropolitan Policy Programs.

GouINI A. (2001), "Demographic Trends and Population Policies», Futures, 33, pp. 27-41, http://dx.doi.org/10.1016/S0016-3287(00)00051-3.

Hall R., Odgen P. (2003), "The Rise of Living Alone in Inner London: Trends Among the Population of Working Age», Environment and Planning, A 35 (5), pp. 871-888, http://dx.doi.org/10.1068/a3549.

Kabisch N., HAASE D., HAASE A. (2009), «Evolving Reurbanisation? Spatio-Temporal Dynamics as Exemplified by the East German City of Leipzig», Urban Studies, 47 (5) pp. 967-990, http://dx.doi.org/10.1177/0042098009353072.

LEES L. (2004), «The Emancipatory City? Paradoxes and Possibilities». London, Sage, $243 \mathrm{p}$.

Lesthaeghe R. (1995), "The Second Demographic Transition in Western Countries: An Interpretation", Gender and Family Change in Industrialised Countries, K. O. MASON, M. JENSEN (eds), Oxford, Clarendon Press, pp. 17-62.

López-GaY A. (2008), Canvis residencials i moviments migratoris en la renovación demogràfica de Barcelona, Barcelona, Consell de Treball, Econòmic i Social de Catalunya.

López-GaY A., Mulder C. H. (2012), «Implicaciones del tamaño de las generaciones en la movilidad residencial: el caso de Barcelona», La población en clave territorial. Actas del XIII Congreso de la Población Española, Santander, Asociación de Geógrafos Españoles y Universidad de Cantabria, pp. 108-116.

Módenes J. A. (1998), Flujos espaciales e itinerarios biográficos: La movilidad residencial en el área de Barcelona, Tesis doctoral, dirigida per Anna Cabré, leída en el Departamento de Geografía de la Universitat Autònoma de Barcelona, Mimeo.

MusteRD S. (2006), "Segregation, Urban Space and the Resurgent City», Urban Studies, 43 (8), pp. 1 325-1 340, http://dx.doi.org/10.1080/00420980600776418. 
NeL·LO O. (2004), «¿Cambio de siglo, cambio de ciclo? Las grandes ciudades españolas en el umbral del siglo XXi», Ciudad y Territorio. Estudios territoriales, 141-142, pp. 523-542.

NystRöm J. (1992), "The Cyclical Urbanization Model. A Critical Analysis», Geografiska Annaler, Series B, Human Geography, 74 (2), pp. 133-144, http:// dx.doi.org/10.2307/490569.

Ogden P. E., Hall R. (2000), "Households, Reurbanisation and the Rise of Living Alone in the Principal French Cities, 1975-90», Urban Studies, 37 (2), pp. 367-390, http://dx.doi.org/10.1080/0042098002230.

ReCAÑo J. (2004), "Migraciones internas y distribución espacial de la población española», Informe sobre la situación demogràfica en España, J. LEAL (ed), Madrid, Fundación Fernando Abril Martorell, pp. 187-228.

RÉrAT P. (2012), «The New Demographic Growth of Cities The Case of Reurbanisation in Switzerland», Urban Studies, 49 (5), pp. 1107-1 125, http://dx.doi.org/ 10.1177/0042098011408935.

Rodenas C., MARTí M. (2006), "Migraciones: ¿qué describen el censo de 2001 y la Estadística de Variaciones Residenciales?», IX Encuentro de Economía Aplicada, Jaén, 8-10 junio 2006.

Rodenas C., MARTí M. (2010), «Algunas lecciones acerca de cómo medir el flujo migratorio: el caso de España», XIII Encuentro de Economía Aplicada, Seville, 10 y 11 de junio de 2010.

Rogers A. (1975), Introduction to Multiregional Mathematical Demography. New York, John Wiley.

Storper M., Manville M. (2006), «Behaviour, Preferences and Cities: Urban Theory and Urban Resurgence», Urban Studies, 43 (8), pp. 1 231-1 246, http://dx.doi.org/ 10.1080/00420980600775642.

TERÁN F. (1999), Historia del urbanismo en España, Siglos XIX y XX, Madrid, Cátedra.

Van den Berg L., Drewett R., KlaAsen L. H., Rossi A., Vijverberg C. H. (1982), Urban Europe: A study of growth and decline, Pergamon, Oxford.

VINUESA J. (2005), "Dinàmica demogràfica, mercado de vivienda y territorio», Papeles de Economía Española, 104, pp. 253-269. 